\title{
The 8x8 Layer Model Consciousness-Intelligence- Knowledge Pyramid, and the Platonic Perspectives
}

https://doi.org/10.3991/ijes.v9i2.22497

\author{
Athanasios Drigas $\left.{ }^{\bowtie}\right)$, Lizeta N. Bakola \\ N.C.S.R. 'Demokritos', Athens, Greece \\ dr@it.demokritos.gr
}

\begin{abstract}
The concept of knowledge is an issue that concerns a swarm of scientists. In now days a battery of researches are trying to detect appropriate strategies to improve cognitive and metacognitive skills. Since ancient times many questions have been raised about what knowledge is (what we mean when we say that someone knows something or what we attribute to a person who we say knows something) and how we can gain knowledge. Moreover how knowledge and information in general is influenced by its transmission is also an important and widely debated problem, which takes different forms depending on the ways (philosophy) or media (technologies) and the era of transmission. In this article we will try to review the pyramid of knowledge in the process of the years getting started from the era of antiquity by affiliating its data with the musings of the Greek philosophers to prove that all the philosophical prepossessions and theories of the past are timelessness and undisputed.
\end{abstract}

Keywords-Pyramid of knowledge, philosophy, Greek philosophers, Plato

\section{$1 \quad$ Introduction}

The problem of the nature and provenance of human knowledge is rather one of the fundamental problems of humanity. Perhaps it is one of those cardinal problems of humanity to which we cannot match any concrete historic beginning, since the earliest vestiges of it are found in the primitive semblance of mystical and religious thinking. Even in myth and religion all of which is distinctive of human is associated with the miracle of knowledge [1]. This miracle goaded human into discovering his propinquity with God and his differences concurrently and moreover in the consciousness that there is not only one absolute knowledge and truth. The Greeks were the first who inaugurated a new kind of cognitional brainstorm that we can call "philosophy". They were the fist who wondered and posed questions about the constitution of the world and wanted to understand the procedure of the alteration, the genesis and the transformation of subjects. Not only they put a set of questions but also, they were looking for new kinds of answers. The Greeks were cerebrating for the first time about the rules of argumentation and proof [2]. Additionally, all their effort was focused on the problem of knowledge and how to acquire it. 
Over the years, from the Theory of Cognitive Development of Piaget (Fig. 1.) and the Social Development Theory of Vygotsky (Fig. 2.) to the Taxonomy of Learning Domains of Bloom \& Anderson/Krathwohl (Fig. 3., 4.) and the Theory of Multiple Intelligences of Gardner (Fig. 5.) all the work of these scientists and more other developmental psychologists has become the pillar of the extended research and theory in developmental cognition over the past several decades [3, 4]. Furthermore, from the Bloom's Taxonomy of Learning Domains to Carl Rogers (Fig. 6.) and Maslow pyramid of knowledge (Fig. 7.), newly we reached to another model of knowledge matrix witch belong to Drigas, A. \& Pappas, M. (2017) which is called "The Consciousness-Intelligence-Knowledge Pyramid" [5] (Fig. 8.). In this article we will try to match the stages of the procedure of knowledge that the scientists have proposed over the years with the meditation of the ancient philosophers and more specifically with the Plato philosophy. Our basic guide will be the last pyramid of knowledge as it's gathering all the data and, into the bargain is adding the concept of a cognitive-based angle to the procedure of the acquisition of knowledge.

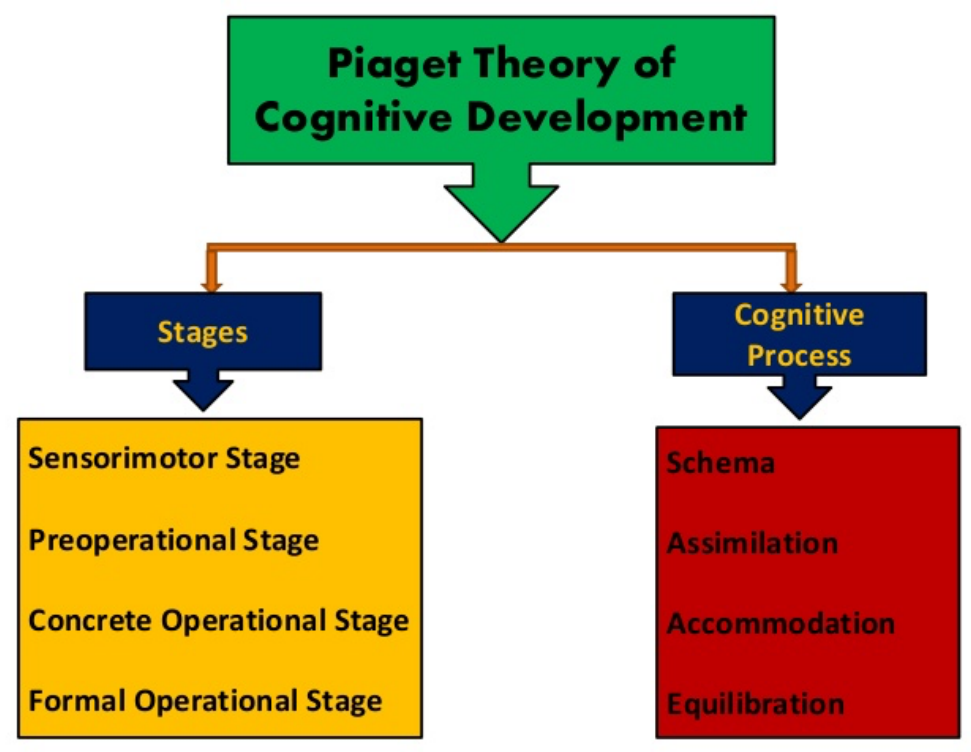

Fig. 1. Piaget Theory of Cognitive development

https://www.learningclassesonline.com/2020/02/jean-piaget-theory-of-cognitivedevelopment.html 
Paper-The 8x8 Layer Model Consciousness-Intelligence-Knowledge Pyramid, and the Platonic..

\begin{tabular}{|c|c|c|}
\hline & Piaget & Vygotsky \\
\hline $\begin{array}{l}\text { Defining } \\
\text { Characteristics }\end{array}$ & $\begin{array}{l}\text { Stages, development drives } \\
\text { learning, learner centered }\end{array}$ & $\begin{array}{l}\text { Social interactions, Zone of Proximal } \\
\text { Development, learning drives } \\
\text { development }\end{array}$ \\
\hline $\begin{array}{l}\text { Mechanisms of } \\
\text { Change }\end{array}$ & $\begin{array}{l}\text { Innate development, stages, } \\
\text { assimilation, accommodation, } \\
\text { equilibration }\end{array}$ & $\begin{array}{l}\text { Scaffolding, social interactions, } \\
\text { cultural development, internalization }\end{array}$ \\
\hline Readiness & $\begin{array}{l}\text { Genetic development growth, } \\
\text { biological stages, has to be } \\
\text { developmentally appropriate }\end{array}$ & $\begin{array}{l}\text { ZPD has to contain the capabilities } \\
\text { that are being taught, scaffolding }\end{array}$ \\
\hline Role of Student & $\begin{array}{l}\text { Actively manipulates } \\
\text { objects/ideas, continually } \\
\text { invents/reinvents knowledge } \\
\text { through interaction with the world }\end{array}$ & $\begin{array}{l}\text { Interact with instructor, peers, and } \\
\text { socio-cultural environment to solve } \\
\text { problems. }\end{array}$ \\
\hline $\begin{array}{l}\text { Role of Teacher } \\
\text { and Classroom }\end{array}$ & $\begin{array}{l}\text { Provide environment that } \\
\text { encourages students to interact } \\
\text { and ask probing questions. }\end{array}$ & $\begin{array}{l}\text { Engage learners in socially-organized } \\
\text { activities, provide scaffolding for } \\
\text { learner. }\end{array}$ \\
\hline Endpoints & $\begin{array}{l}\text { Hypothetically everyone can reach } \\
\text { the endpoint. }\end{array}$ & Learning how to think. \\
\hline
\end{tabular}

Fig. 2. Comparing the two theories of Piaget \& Vygotsky

https://www.simplypsychology.org/vygotsky.html

\section{Bloom's Taxonomy}

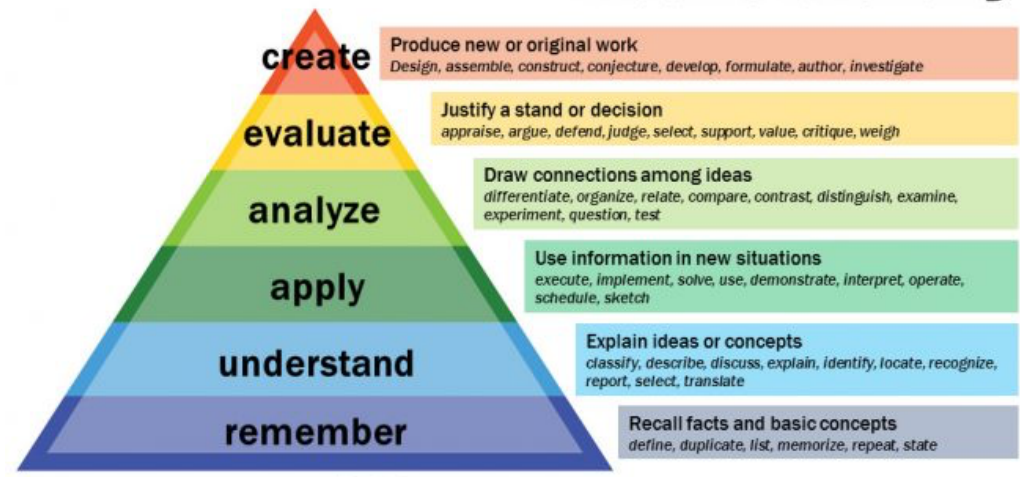

Q. 0 Vanderbit University Center for Teachins

Fig. 3. Bloom's Taxonomy of Learning Domains

https://cft.vanderbilt.edu/guides-sub-pages/blooms-taxonomy 


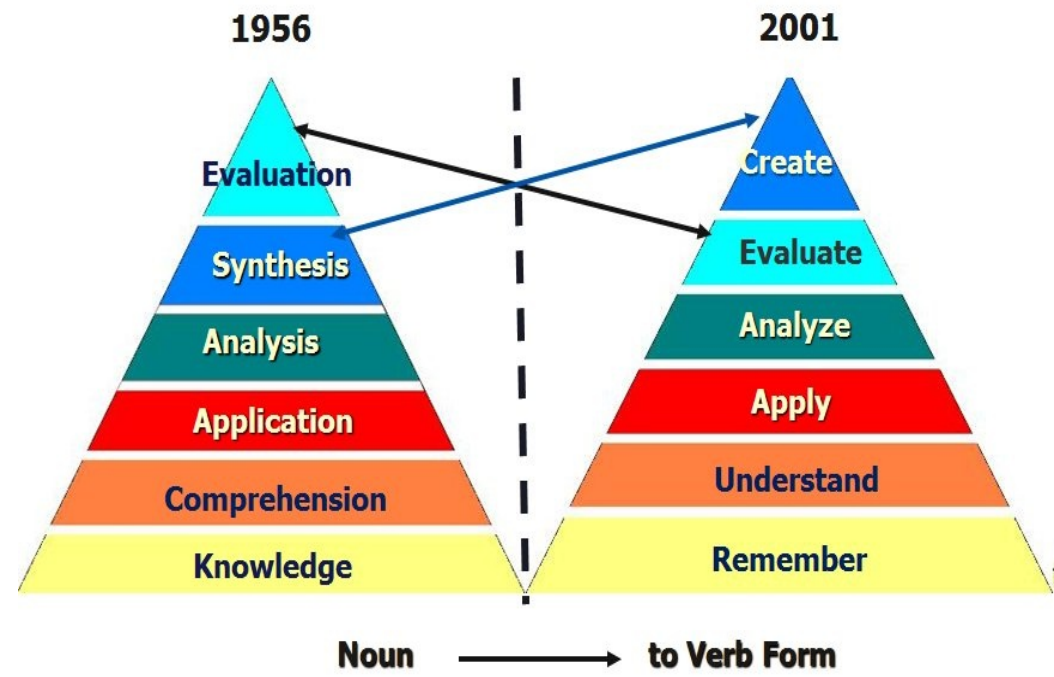

Fig. 4. Bloom's vs Anderson's/Krathwohl's Taxonomy

https://dreamlikechild.weebly.com/blooms-vs-andersonkrathwohl-taxonomy-revised.html

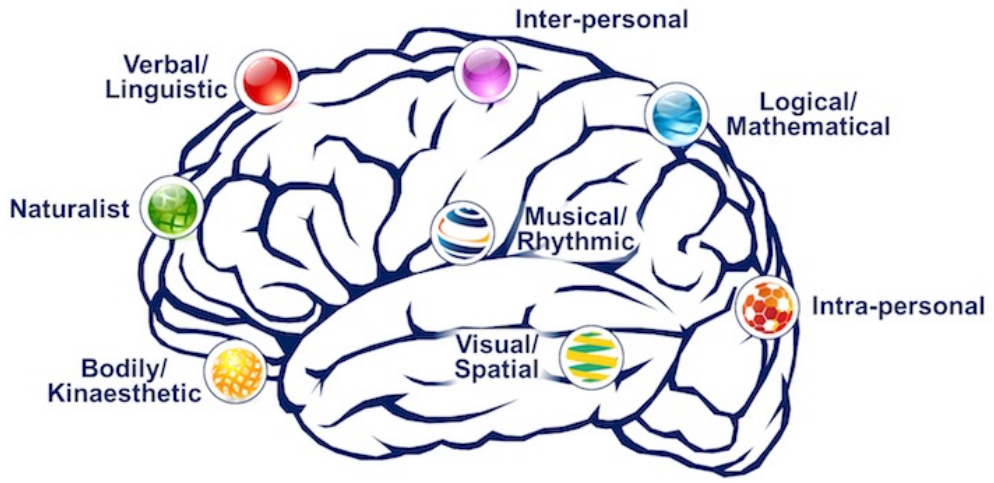

Multiple Intelligences

Howard Gardner: Frames of Mind

Fig. 5. Multiple Intelligences/ Howard Gardner

https://www.pocketbook.co.uk/blog/2018/02/06/multiple-intelligences/ 


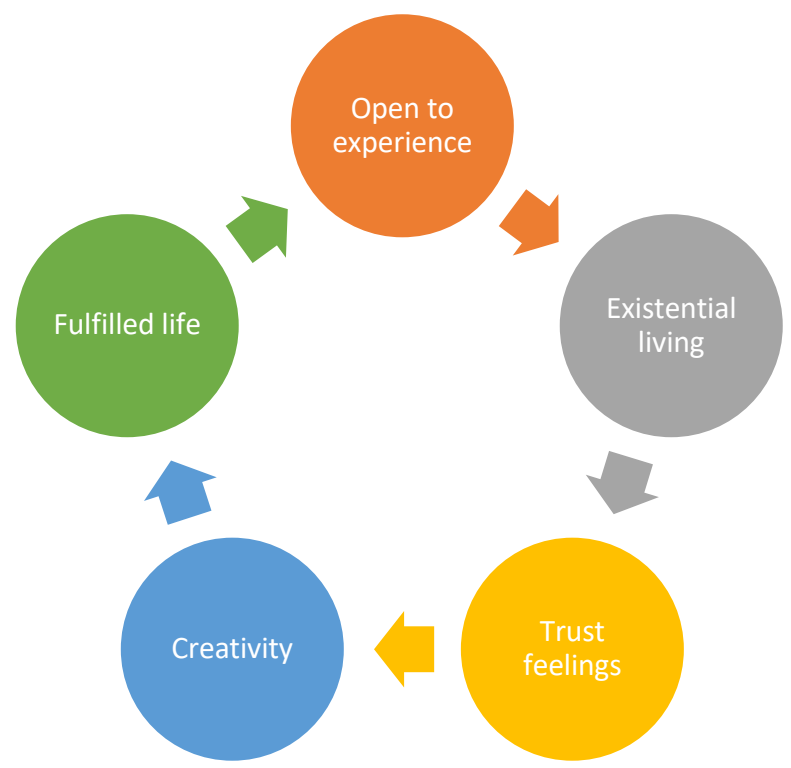

Fig. 6. The 5 Characteristics of the Fully Functioning Person by Rogers

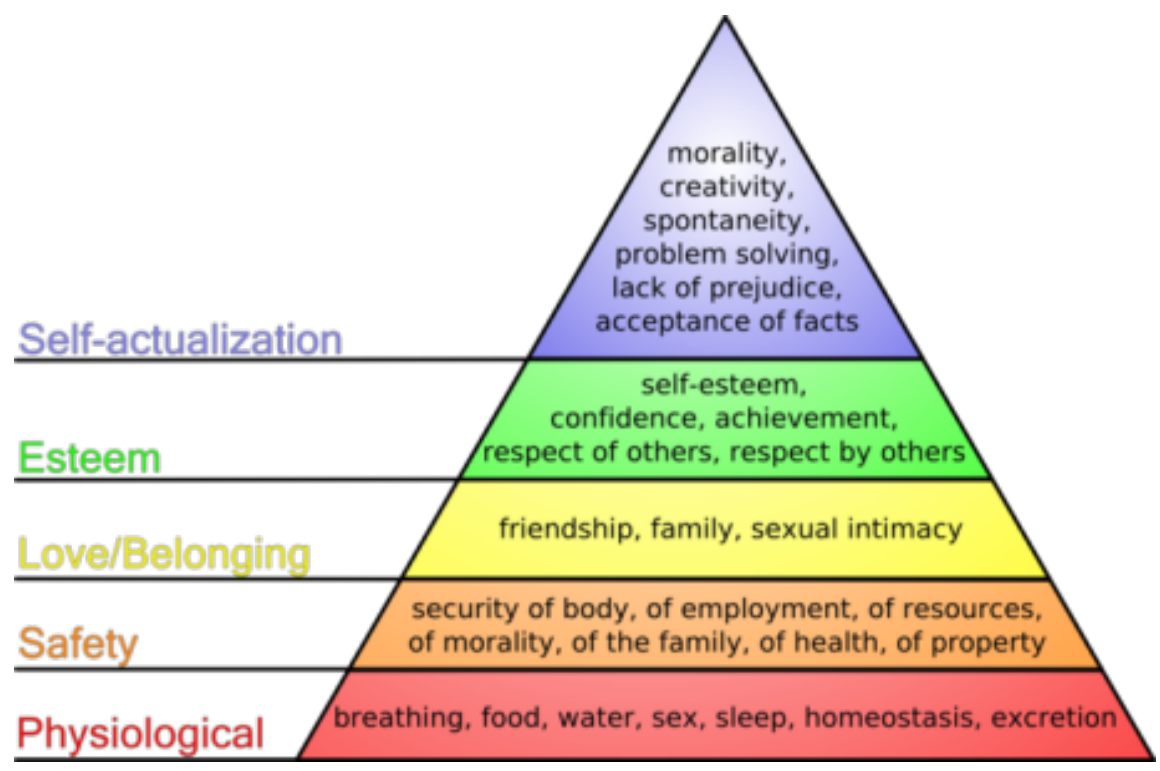

Fig. 7. Maslow's Hierarchy of Needs

https://www.ukessays.com/essays/psychology/comparison-maslow-rogers-theories1124.php 


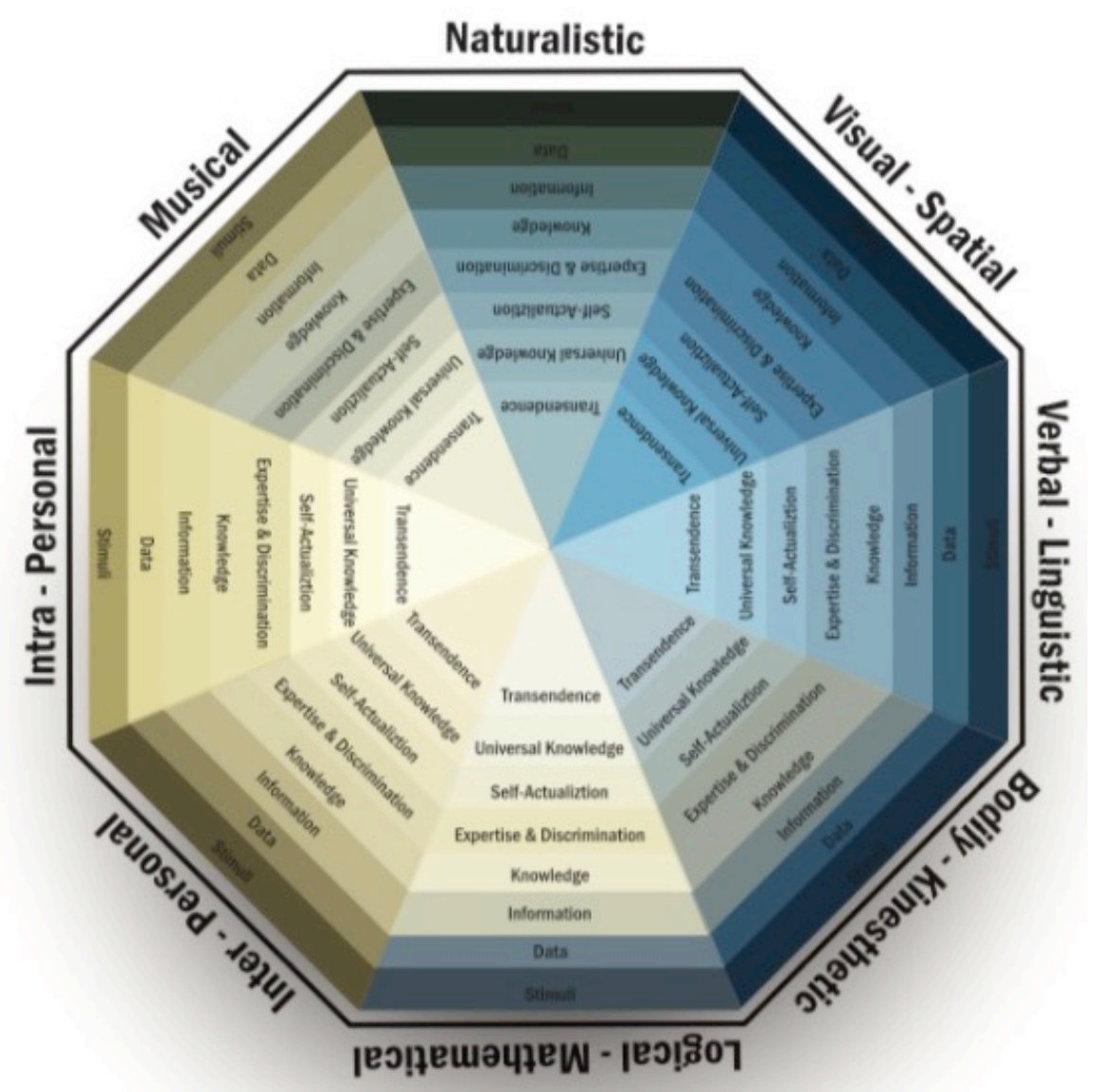

Fig. 8. The Consciousness-Intelligence-Knowledge Pyramid

https://onlinejour.journals.publicknowledgeproject.org/index.php/ijes/article/viewFile/7680/4615

\section{The Greek Philosophers and the Problem of Knowledge}

Greek philosophy appeared in the early of $6^{\text {th }}$ century. The mythology of the Olympian Gods, which until then was a central feature of Greek culture and influenced the thought, the language and the behavior of the ancient Greeks, seems to have given its baton to the emergence of new, philosophical ways of thinking, without replacing itself, but usually alongside her or sometimes in close relationship with her. The first philosophers did not just establish a new set of questions. They also looked for new kinds of answers. More specifically, Homer and Hesiod were not philosophers and did not practice philosophy. On the other hand, Thales, Pythagoras and Heraclitus, although they were living in a culture steeped in mythology, they inaugu- 
rated a kind of spiritual pursuit, that we can call philosophy [6]. In the first place of their thinking was the question of the origin and of the cardinal component of the world. Next, they tried to solve the problem of the immutability and transmutation of subjects as well. We can cite as example a dictum of Heraclitus in which he asseverated that "Everything is volatile and nothing stays consistent or immovable" [7]

Behind these discussions about the reality of things and the problem of transmutation was emerged another burning issue that also encountered from the first Greek philosophers and that was the problem of knowledge. For the first time the problem of knowledge was broached in the $5^{\text {th }}$ century, at the discussion of alteration and immutability [8]. Parmenides condemned the senses of humans as not reliable and championed that the truth can only be internalized with the aid of cognition. Democritus, in an excerpt which has been saved, abstracts "two kinds of knowledge: the original and the recondite one. At the recondite belongs: the vision, the audition, the olfaction, the taste, the touch." [9]. Empedocles supported that the senses may not be perfect but they can be useful in case they can be used with perception. The answer was given from Plato with his "Theory of Forms". According Plato, there are two areas of reality: 1) the world (what we perceive with our senses) and 2) the area of forms or ideas (the ideas as the non-physical essences and imaginary entities). Afterward we will analyze the Plato's theory and prove its affiliation with the theories of knowledge and even more with the Consciousness-Intelligence-Knowledge Pyramid.

\section{Plato's Theories and the Pyramid of Knowledge}

\subsection{The definition of knowledge}

Trying to approach the denotation of philosophy it would be useful to start from the question of what "philosophy" means. Moreover, in order to understand the answers that Plato has given in this inquiry and to comprehend in the same time the particularity of the platonic perception about philosophy, we have to probe firstly which was the meaning for the word "philosophy" for everyone who was using it and for the Plato as well [10].

According to Clement of Alexandria (Stromata V 141, II 421), the word of "philosopher" was used for the first time by Heraclitus: "Because the men who love wisdom should be cognoscente of many things". [10, 11, 12 ]. On the other side, Porphyrius (Peri apochēs empsychōn II 49) cites that: " The cognoscente of many things is the real philosopher"[13]. In view of the above, "philosopher" is the individual who is striving for the structured gnosis which demands aliquots studies. Heraclitus perhaps was meaning that philosopher is someone who loves the wisdom which is constituted in the knowledge of logos. In ancient Greece "logos" was the moderation and the order of the entire world. The unlimited gnosis was only for Gods. That's why they used to believe that a human could never be wise but only a friend of wisdom (that's the meaning of "philosopher").

Thus, firstly "philosophy" was meaning the aim of knowledge and education in a general significance and "philosopher" was meaning the person who is aiming at 
gnosis and education. The same intent of these words can also be found in the texts of Herodotus (I 30, 2) and Thucydides (II 40) as well [10, 14].

Furthermore, according to presocratic philosophers, in order that someone wanted to reach true wisdom, it was necessary to discover the real of the facts. The quest of reality was the main target of sophists and philosophers but with a lot of differences for each part.

\subsection{Plato's theories in comparison with the basic forms of consciousness- intelligence-knowledge pyramid}

Studying in parallel the texts of Plato and the basic forms of the ConsciousnessIntelligence-Knowledge Pyramid, it's really impressive to discover that there are plenty of commonalities. In fact, they share the same concepts as detailed below. Following we will describe some of the fundamental theories of Plato indicating the main forms of the pyramid.

Plato is one of the world's most widely known as well as most read and studied Athenian philosophers. He lived during the Classical period in Ancient Greece (428348 BC) and he was the founder of the Platonist school of thought and the Academy, which was the first institution of higher learning in the Western world. As student of Socrates he was primarily influenced by him but he was also affected by Heraclitus, Parmenides and the Pythagoreans. He was the teacher of Aristotle as well [15].

The main lynchpin of Plato's philosophy is his Theory of Ideas or Forms. It was through this basic perception that he tried to confront some important philosophical issues and formulate interesting views on them, such as his theory of knowledge as anamnesis, his theory about the moral behavior of individual, his theory of the ideal society or his theory of art [16].

Verbal-linguistic: At the beginning of the $4^{\text {th }}$ century, there was no established way of writing philosophy. Plato chooses to write dialogues while he could write treatises such as Anaxagoras, Democritus and the sophists or poetry like Parmenides. Initially, he seems to have been influenced by his teacher Socrates, where throughout his life he used the dialectical art, rejecting the written word. On the other hand, his choice is harmonized with his belief that philosophy is primarily a course, a brainstorming and the dialogue is a written text which is close to the oral exchange so that removes the disadvantages of the written word. In that way, it has been created a new literary genre called philosophical dialogue. The main protagonist of his dialogues is Socrates [17].

With the Theory of Ideas, Plato is considered as the father of the philosophical current, called Idealism. Plato was defined them as ideas beings, that is, the objects of knowledge which could be defined but on the other hand which were not identified with the real world, despite their existence in it. This theory is based on the theory of transmigration, according to which the soul does not die after the death of man, but goes and lives in another organism. Actually, with this theory Plato attempted to solve the main problem that the philosophers inherited from the Pre-Socratic cogitators. It's about the question of the structure of the world and especially if the subjects are in a 
ceaseless fluidity, according Heraclitus or, contrary to the seeming flow, there is also some constancy which enables us to have a good knowledge of it $[16,17]$.

Visual-spatial: According to the Theory of Ideas, reality is divided into two levels: the perceptible world and conceivable world. To the first one belongs the things and objects that we can apprehend with our senses and whose dominant feature is the variability of the things and events that make it up and in the second one the ideas, which are perceived only with our mind and that is governed by the stability of the beings that makes it up [17].

Intrapersonal: Plato based the acquisition of the real knowledge on his Theory of Ideas. According to him it's not possible for anyone to acquire valid knowledge that is based on senses. For him the reality must be looked into the cerebration and dialectic.

"I thought of that danger, and I was afraid my soul would be blinded if I looked at the things with my eyes and tried to grasp them with any of my senses. So, I thought I must have recourse to conceptions and examine in them the truth of facts (Plato, Phaedo II. 99e) $[17,18]$.

Furthermore, in his book Republic and in particular in the chapter VII, which called the Allegory of the Cave, Plato symbolizes the visible-perceptible word with the cave and the conceivable word with the word abroad.

"This entire allegory, I said, you may now append, dear Glaucon, to the previous argument; the prison-house is the world of sight, the light of the fire is the sun, and you will not misapprehend me if you interpret the journey upwards to be the ascent of the soul into the intellectual world according to my poor belief, which, at your desire, I have expressed - whether rightly or wrongly God knows. But, whether true or false, my opinion is that in the world of knowledge the idea of good appears last of all, and is seen only with an effort; and, when seen, is also inferred to be the universal author of all things beautiful and right, parent of light and of the lord of light in this visible world, and the immediate source of reason and truth in the intellectual; and that this is the power upon which he who would act rationally either in public or private life must have his eye fixed" (Plato, Rep. VII).

"All in all", I responded, "those who were chained would consider nothing besides the shadows of the artifacts as the unhidden" (Plato, Rep. VII. 514a-515c) [19].

Musical: Plato, in addition to being a great philosopher, was also a great musician. Faithful to tradition, conservative and inexorable in his beliefs, he expressed himself with simplicity and clarity. He deeply and firmly believed that the music is a divine art that has lofty purposes and is therefore an extremely appropriate and effective means of education.

"And therefore, I said, Glaucon, musical training is a more potent instrument than any other, because rhythm and harmony find their way into the inward places of the soul, on which they mightily fasten, imparting grace, and making the soul of him who is rightly educated graceful, or of him who is ill-educated ungraceful; and also because he who has received this true education of the inner being will most shrewdly perceive omissions or faults in art and nature, and with a true taste, while he praises and rejoices over and receives into his soul the good, and becomes noble and good, he will justly blame and hate the bad, now in the days of his youth, even before he is able to know the reason why; and when reason comes he will recognize and salute the 
friend with whom his education has made him long familiar” (Plato, Rep. III. 369a) [20].

"Yes", he said," that would be far the best education for them." And this is not for this reason ,Glauco," I said," that education in music is most sovereign, because more than anything else rhythm and harmony find their way to the inmost soul and take strongest hold upon it, bringing with them and imparting grace, if someone is rightly trained." (Plato, Rep. III. 401d) [21]

Logical-mathematical: Moreover, Plato quickly realized that the theory of forms fit perfectly into the mathematical thought. He is even more impressive when he finds that the mathematical constructions are applicable in the real word. Mathematical sciences have a special significance in the educational program of the Platonic Republic. Plato asks to the future philosophers to learn from the mathematic science two things: the way in which mathematicians export from the general the more specific and finally the ideal character of the mathematical entities. For him, those who know exactly the various objects in space do not expect to learn about them by looking around or feel disappointed because they don't see in their senses any perfect triangle or circle.

"Yes", I said, "and now having spoken of it, I must add how charming the science of mathematic is! And in how many ways it is subtle and useful tool to achieve our purposes, if pursued in the spirit of a philosopher." (Plato, Rep. VII) [20].

"I mean, as I was saying, that arithmetic has a very great and elevating effect, compelling the soul to reason about abstract number, and rebelling against the introduction of visible or tangible objects into the argument." (Plato, Rep. VII) [20].

Bodilkinesthetic / Inter-personal: Additionally, philosophical education as understood by Plato is a laborious and long process. It includes the balanced development of the student's body and soul (gymnastic, music) the development of his physical skills, his gradual acquaintance with the sciences and especially with mathematics, as mentioned above and finally his initiation into philosophy. By the dialectical method the individual can find the truth and philosophy as the content of a true education is addressed to all [17].

"And what shall be their education? Can we find a better than the traditional sort? - and this has two divisions, gymnastic for the body, and music for the soul.

True.

Shall we begin education with music, and go on to gymnastic afterwards?

By all means" (Plato, Rep. II) [20].

"In childhood and youth their study, and what philosophy they learn, should be suited to their tender years: during this period while they are growing up towards manhood, the chief and special care should be given to their bodies that they may have them to use in the service of philosophy; as life advances and the intellect begins to mature, let them increase the gymnastics of the soul; but when the strength of our citizens fails and is past civil and military duties, then let them range at will and engage in no serious labour, as we intend them to live happily here, and to crown this life with a similar happiness in another" (Plato, Rep. VI) [20].

"And so with dialectic; when a person starts on the discovery of the absolute by the light of reason only, and without any assistance of sense, and perseveres until by pure 
intelligence he arrives at the perception of the absolute good, he at last finds himself at the end of the intellectual world, as in the case of sight at the end of the visible.

Exactly, he said.

Then this is the progress which you call dialectic?

True.

But the release of the prisoners from chains, and their translation from the shadows to the images and to the light, and the ascent from the underground den to the sun, while in his presence they are vainly trying to look on animals and plants and the light of the sun, but are able to perceive even with their weak eyes the images in the water (which are divine), and are the shadows of true existence (not shadows of images cast by a light of fire, which compared with the sun is only an image)-this power of elevating the highest principle in the soul to the contemplation of that which is best in existence, with which we may compare the raising of that faculty which is the very light of the body to the sight of that which is brightest in the material and visible world - this power is given, as I was saying, by all that study and pursuit of the arts which has been described." (Plato, Rep. VII) [20].

Naturalistic: The ancient Greeks understood the necessity of the moderation for their own safety. They realized that the moderation leads to harmony with nature. When people were attuned to nature, they could coexist peacefully between each other, to the contrary, when they disrupted it they were forced to suffer the consequences. The sense of moderation, both in the same respect for the nature as well as the human pursuits was the golden rule and guide for the ancient Greeks. In various texts of Greek philosophers "about nature" is recognized the basic principle of the unity of nature, the effect of nature on human behavior and the acceptance of natural harmony as a moderation of human society. In Heraclitus and Plato are detected its meanings of entropy and recycling basic notions on ecology and environmental protection $[22,23,24]$.

\section{The Stages of the Pyramid and the Plato's Theories}

In this chapter we will try to prove that the theories of Plato not only can be matched with the basic forms of the Consciousness-Intelligence-Knowledge Pyramid but also can be responded to its stages. Moreover, there is a lot of interplay between the stages as well as dependence.

Stimuli: According to Blake \& Sekuler (2006), there have been many studies about perception and attention that support the idea that there is a plethora of knowledge available to an individual at any given moment. In the other hand the main component and the basic key to the beginning stages of perception demands the attention of the observer on some focal point or stimulus [25]. For Plato our sensory stimuli are "impoverished". In his dialogue Phaedo, he expresses the "Imperfection Argument" that is both an argument for the existence of Forms and an argument for our possession of "a priori concepts". According to Plato we never experience perfect shapes (triangles, circles, etc.), although we have these concepts and we classify things accordingly [26]. 
"Whence did we derive the knowledge of it? Is it not from the things we were just speaking of? Did we not, by seeing equal pieces of wood or stones or other things, derive from them knowledge of abstract equality, which is another thing? Or do you not think it is another thing? Look at the matter in this way. Do not equal stones and pieces of wood, though they remain the same, sometimes appear to us equal in one respect and unequal in another?"

Certainly." (Plat. Phaedo 74b)

"And we agree, also, that we have not gained knowledge of it, and that it is impossible to gain this knowledge, except by sight or touch or some other of the senses? I consider that all the senses are alike." (Plat. Phaedo 75a) [27].

Data / Information / Knowledge: In Plato's Republic and specifically in the Book VII, which refers to the Allegory of the Cave, Jowett, B. indicates that the cave or den represents the world of sight, the fire represents the sun and the way upwards represents the way to knowledge. And in the world of knowledge the idea of good is the last seen and with difficulty, but when seen is inferred to be the author of good and rightparent of the lord of light in this world, and of truth and understanding in the other. So, he who attains to the beatific vision is always going upwards. But blindness is of two kinds, and may be caused either by passing out of darkness, and a man of sense will distinguish between them. In this parable we can see a further lesson. It's about conversion; we can see the truth if we turn our eyes to the light. Instruction is like giving eyes to the blind, but as the faculty of sight was always there, the soul only requires to be turned round towards the light [20]. All these above essentially refer to the way that individuals, from the moment they receive any stimuli and locate the data, will turn them into information which they will have to process and discern correctly in order to reach knowledge.

"And now, I said, let me show in a figure how far our nature is enlightened or unenlightened: - behold! Human beings living in a underground den, which has a mouth open towards the light and reaching all along the den; here they have been from their childhood, and have their legs and necks chained so that they cannot move, and can only see before them, being prevented by the chains from turning round their heads. Above and behind them a fire is blazing at a distance, and between the fire and the prisoners there is a raised way; and you will see, if you look, a low wall built along the way, like the screen which marionette players have in front of them, over which they show the puppets"

"And now look again, and see what will naturally follow if the prisoners are released and disabused of their error. At first, when any of them is liberated and compelled suddenly to stand up and turn his neck round and walk and look towards the light, he will suffer sharp pains; the glare will distress him, and he will be unable to see the realities of which in his former state he had seen the shadows; and then conceive someone saying to him, that what he saw before was an illusion, but that now, when he is approaching nearer to being and his eye is turned towards more real existence, he has a clearer vision,- - what will be his reply? And you may further imagine that his instructor is pointing to the objects as they pass and requiring him to name them, - will he not be perplexed? Will he not fancy that the shadows which he formerly saw are truer than the objects which are now shown to him? 
Far truer.

And if he is compelled to look straight at the light, will he not have a pain in his eyes which will make him turn away to take refuge in the objects of vision which he can see, and which he will conceive to be in reality clearer than the things which are now being shown to him?

True, he said" (Plato, Rep. VII) [20].

Moreover, it's really impressive that Plato has also mentioned the cognitive functions such as memory and sagacity which are essential to intelligence as well as the different stages of their development.

"And do not suppose that there will be many of them; for the gifts which were deemed by us to be essential rarely grow together; they are mostly found in shreds and patches.

What do you mean? he said.

You are aware, I replied, that quick intelligence, memory, sagacity, cleverness, and similar qualities, do not often grow together, and that persons who possess them and are at the same time high-spirited and magnanimous are not so constituted by nature as to live orderly and in a peaceful and settled manner; they are driven any way by their impulses, and all solid principle goes out of them.

Very true, he said." (Plato, Rep. VI) [20].

Expertise and Discrimination: Plato believed that in order to become a good ruler, a person must be aware of "Agathon" and this can be achieved only by combining spiritual and moral discipline. In addition, he promoted that it needs a lot of education for someone to succeed in his leadership duties. The main pursuit of the Platonic "Republic" is education. And the main regulators of all educational subjects are the philosophers- "archondes" (masters). These are who combine the knowledge with power. This, however, presupposes that the bodies of the Platonic republic are a model of morality and education in order to pursue a correct and productive educational policy. As a conclusion, its civil servant is the scientifically trained soldier or a militarily trained scientist [28].

"And may we not say, Adeimantus, that the most gifted minds, when they are illeducated, become pre-eminently bad?" (Plato, Rep.VI) [20].

"Then this is a kind of knowledge which legislation may fitly prescribe; and we must endeavour to persuade those who are to be the principal men of our State to go and learn arithmetic, not as amateurs, but they must carry on the study until they see the nature of numbers with the mind only; nor again, like merchants or retail-traders, with a view to buying or selling, but for the sake of their military use, and of the soul herself; and because this will be the easiest way for her to pass from becoming to truth and being.

That is excellent, he said.

Yes, I said, and now having spoken of it, I must add how charming the science is! and in how many ways it conduces to our desired end, if pursued in the spirit of a philosopher, and not of a shopkeeper!» (Plato, Rep. VII) [20].

Self- Actualization: The concept of self-actualization could be identified with the model of the ideal philosopher-king in Plato's theory: a man who has become wise and free from all kinds of needs, works for the sake of society by philosophizing and 
reigning. At the same time, if every human being ever reached self-realization, then there would be no need for social influence or for prime minister or any kind of authority, as every human being would be a completed cogitative being without the need of leading.

"Observe, Glaucon, that there will be no injustice in compelling our philosophers to have a care and providence of others; we shall explain to them that in other States, men of their class are not obliged to share in the toils of politics: and this is reasonable, for they grow up at their own sweet will, and the government would rather not have them. Being self-taught, they cannot be expected to show any gratitude for a culture which they have never received. But we have brought you into the world to be rulers of the hive, kings of yourselves and of the other citizens, and have educated you far better and more perfectly than they have been educated, and you are better able to share in the double duty. Wherefore each of you, when his turn comes, must go down to the general underground abode, and get the habit of seeing in the dark. When you have acquired the habit, you will see ten thousand times better than the inhabitants of the den, and you will know what the several images are, and what they represent, because you have seen the beautiful and just and good in their truth. And thus our State, which is also yours, will be a reality, and not a dream only, and will be administered in a spirit unlike that of other States, in which men fight with one another about shadows only and are distracted in the struggle for power, which in their eyes is a great good. Whereas the truth is that the State in which the rulers are most reluctant to govern is always the best and most quietly governed, and the State in which they are most eager, the worst.

Quite true, he replied." (Plato, Rep. VII) [20].

Universal Knowledge: In Timaeus, Plato narrates the creation of the world, which he presents as a work of art, where the rational order dominates (in the firmament) and where is associated with affair of analogy with humans by a geometric god. With mathematical astronomy Plato proves that the sky is a perfect space because all the planets have an eternal, regular and circular motion. To man, who is a miniature of the world, the corresponding space is the immortal part of the soul, the logical. So, according to him all people have the natural ability to develop their logic.

"Why did the Creator make the world? He was good, and therefore not jealous, and being free from jealousy he desired that all things should be like him. Wherefore he set in order the visible world, which he found in disorder. Now he who is the best could only create the fairest; and reflecting that of visible things the intelligent is superior to the unintelligent, he put intelligence in soul and soul in body, and framed the universe to be the best and fairest work in the order of nature, and the world became a living soul through the providence of God." (Plato, Tim. 29e) [29].

Transcendence: Plato promotes the idea that the human soul is immortal and flows from the eternity of transcendental Forms. According to him, the soul is also the place where can be met all the inclinations of life, senses and cognition, genesis and content, matter and spirit. The soul radiates for all the elements and for all the directions of the world. Via desires it turns to matter and via "logo" to the word of Forms. The truth can be found in the divine realm of eternal and immaterial forms and ideas rather than in the changing and deceptive shadows of the empirical and material reality. In the simile of the Cave, the ascent and the rise from the cave is a holistic 
transformation of being. It's an elevation into a higher level of wisdom and perfection. It's the rite of passage toward the immutable, the eternal, and the absolute. Then, the human being is achieved the highest part of his route, where are the Forms as well as the last and the top which is the "Agathon" [30].

\section{Conclusion}

Platonic ideas indicate the highest level of being; they offer the criterion of truth and function as absolute moral values. The conquest of Plato's ideas leads man to bliss. This conquest seems to be extremely difficult but not improbable. On the other hand, the Consciousness-Intelligence-Knowledge Pyramid is based on the main goals that a person should cultivate in order to achieve transcendence. All these forms not only are identical but also aim at the same purpose. As a conclusion it is proved that all the philosophical prepossessions and theories of the past are timelessness and undisputed.

\section{References}

[1] The Problem of Knowledge: Philosophy, Science, and History since Hegel. Contributors: Ernst Cassirer - Author, William H. Woglom - Translator, Charles W. Hendel - Translator. Publisher: Yale University Press. Place of publication: New Haven, CT. Publication year: 1950. Page number: iii

[2] David C. Lindberg, The Beginnings of Western Science: The European Scientific Tradition in Philosophical, Religious, and Institutional Context, 600 B.C. to A.D. 1450, 2007 edition, 3. https://doi.org/10.7208/chicago/9780226482064.001.0001

[3] Dr. Marin Vlada, From Piaget and Vygotsky to Bloom and Gardner, Bucharest, January 2015, CNIV Romania, University of Romania, ICVL, http://c3.icvl.eu/2015/th-intel

[4] Anderson, L. W. and Krathwohl, D. R. (Eds.) (2001) A Taxonomy for Learning, Teaching, and Assessing: A Revision of Bloom's Taxonomy of Educational Objectives. Pearson Education Group, Boston, MA.

[5] Drigas, A. S., \& Pappas, M. A. (2017). The Consciousness-Intelligence-Knowledge Pyramid: An 8x8 Layer Model. International Journal of Recent Contributions from Engineering, Science \& IT (iJES), 5(3), 14-25. https://doi.org/10.3991/ijes.v5i3.7680

[6] Paul Venye, Paula Wissing (Translation), Did the Greeks Believe in Their Myths? University of Chicago Press, ISBN 0226854345,1988

[7] Kalfas, B. \& Zografidis, G. (2006). Ancient Greek Philosophers, To Vima,66-69, ISBN 978-960-503-319-4

[8] Kirk, G. S., Raven, J. E., \& Schofield, M. (1983). The presocratic philosophers: A critical history with a selection of texts.,325-422, Cambridge University Press. https://doi.org/ $\underline{10.1017 / \mathrm{cbo} 9780511813375}$

[9] Lloyd, G. E. R. (2012). Early Greek science: Thales to Aristotle. Random House.

[10] Bormann, K. (1973). Platon. Alber.

[11] Lilla, S. R. (2005). Clement of Alexandria: a study in Christian Platonism and Gnosticism. Wipf and Stock Publishers.

[12] Prestige, L. (1929). Clement of Alexandria, "Stromata", 2. 18, and the meaning of Hypostasis'.

[13] De Rhoer, J. (1767). Porphyriu philosophu Pythagoriku Peri apochēs empsychōn biblia tessera. 
[14] Kirk, G. S., Raven, J. E., \& Schofield, M. (1983). The presocratic philosophers: A critical history with a selection of texts. Cambridge University Press. https://doi.org/10.1017/ cbo9780511813375

[15] Gijsbers, V. (2004). Ideals of knowledge: Media from Plato to Wikipedia. Accessed October, 11, 2007.

[16] Taylor, A. E. (2013). Plato: The Man and His Work (RLE: Plato). Routledge. https://doi. org/10.4324/9780203101377

[17] Pelegrinis, N., Theodosios, (1998). The 5 seasons of Philosophy. Ellinika Grammata

[18] Plato. Phaedo, II 99e http://www.perseus.tufts.edu/hopper/text?doc=Perseus $\% 3$ Atext $\%$ 3A1999.01.0170\%3Atext\%3DPhaedo\%3Asection\%3D99e

[19] Sheehan, T. Plato: The Allegory Of The Cave, Republic,VII, 514a, 2 to 517a,7

[20] Jowett, B. (2016). Plato: The Republic. II, III, V, VI, VII https://www.gutenberg.org/ files/1497/1497-h/1497-h.htm\#link2H_4_0004

[21] Plato. Republic, III, 401d http://www.perseus.tufts.edu/hopper/text?doc=Perseus\%3Atext \%3A1999.01.0168\%3Abook\%3D3\%3Asection\%3D401d

[22] Lazou, A., \& Kalachanis, K. (Eds.). Elements of the Philosophy of Nature vol. I.

[23] Mahoney, T. A. (1997). Platonic Ecology, Deep Ecology. The Greeks and the Environment, 45-54.

[24] O’Brien, J. (2020). 5 Plato's statesmen. Modern Leaders: Between Charisma and Trickery. https://doi.org/10.4324/9780429319433-5

[25] Blake, Randolph, and Robert Sekuler. Perception. 5th ed. New York, NY: McGraw-Hill, 2006.

[26] Cohen, S.,Marc, (2006). Phaedo. The "Imperfection Argument" (Phaedo 74-76) https://faculty.washington.edu/smcohen/320/phaedo.htm

[27] Plato., Phaedo, 74b-75a http://www.perseus.tufts.edu/hopper/text?doc=Perseus $\% 3$ Atext $\%$ 3A1999.01.0170\%3Atext\%3DPha

[28] Annas, J. (1981). An introduction to Plato's Republic.

[29] Plato's Tmaeus, 29e-30b, https://trinityinyou.com/platos-timaeus-29e-30b

[30] Peltonen, T. (2019). Transcendence, consciousness and order: Towards a philosophical spirituality of organization in the footsteps of Plato and Eric Voegelin. Philosophy of Management, 18(3), 231-247. https://doi.org/10.1007/s40926-018-00105-6

\section{Authors}

A. Drigas is a Research Director at N.C.S.R. 'Demokritos', Institute of Informatics \& Telecoms Net Media Lab, Mind Brain R\&D, Agia Paraskevi, 153 10, Athens, Greece (dr@,iit.demokritos.gr).

L. Bakola is a PHD Candidate in the Department of Information \& Communication Systems Engineering at the Aegean University in collaboration with the Institute of Informatics and Telecoms of Demokritos. She keeps a philologist academic degree and she has a M.Sc. degree in "Expertise in ICTs and Special Education - Psychopedagogy of Integration" from the Democritus University of Thrace. She is also a research associate at N.C.S.R. 'Demokritos', Institute of Informatics and Telecoms, Net Media Lab, Mind Brain R\&D, Agia Paraskevi, 153 10, Athens, Greece (lizeta79@gmail.com / lizbak@iit.demokritos.gr / bakolalizeta@icsd.aegean.gr).

Article submitted 2021-03-08. Resubmitted 2021-05-09. Final acceptance 2021-05-10. Final version published as submitted by the authors. 